\title{
タングステン粉末の比表面積についで
}

\section{高柳 重 敏**}

Shigetoshi Takayanagi: On the Specific Surface Area of Tungsten Powder. (Study on the Surface States of Tungsten Powder (2)). By the simplified gas adsorption procedure previously reported by the author, an investigation was made of the surface states of tungsten powder prepared by hydrogen reduction. It was found that, while the surfaces of particles of pure tungsten powder were smooth, those of doped tungsten were roughened and covered with a layer of the alkaline components of dopes. The surface area of doped powder was remarkably affected by pure water washing as well as by pickling in dilute alkaline or acidic solutions. The surface area was also changed by oxidation or reduction of the powder. In atmospheric air at room temperature, tungsten powder is oxidized. In such oxidation process, the surface area considerably changed in relation with the transition of oxidation rate. An explanation of these phenomena was proposed with the help of electronmicroscopic observations.

(Received August 24, 1959)

\section{I. 緒}

タングステン粉末の粒度が粉末冶金の焼結工 程 などに 大きな影響を执よぼすことはよく知られている。それ故 酸化タングステンを水素還元して作つた粉末粒子の大き さ, 形状についての研究(1)(2)(3) は非常に多くあるが, 粒 子の表面状態についての研究は殆んどない.しかし同じ 粒度分布の $\mathrm{W}$ 粉末を用い, 同一条件で焼結しても収縮 の度合が著しく違らことが認められている.そしてこの 原因は粒子の表面状態の差によることが示唆されている(4) が, 詳細は明らかにされていない, 著者もまた管球用 W, Mo 線の製造に拈いて, ドープの量や粒度などの他に粒子

***松下電子工業株式会社研究部

* タングステン粉末の表面状態の研究（第 2 報）

(1) C.J.Smithels: Tungsten, 3rd Ed. Chapman \& Hall, (1952), 47.

(2) B.Kopelman: The Physics of Powder Metallurgy, edited by W.E. Kington, McGraw Hill, (1951),303

(3) H.L.Spier and W.L.Waumaker: Philips Res. Rept's, 13(1958), 149.

(4) C.G.Goetze1: Treatise on Powder Metallurgy, Interscience Pub. Inc., 2(1950),13.
の表面状態が非常に大さな影響のあることに與味を抱い た.

著者が前汇考案した簡易ガス吸着法(5)を用いれば短時間 にしかも精度, 再現性を損うことなく粉末束の比表面積の測 定ができる．本報ではこの測定方法を用いてドープ添加や 粉末の弗酸処理扣よび酸化，還元などが W 粉末の比表面 積におよぼす影響を調べ，電子顕微鏡などによる観察結果 と比較検討した結果について報告する.

\section{II. 実 験 試 料}

W 粉末は連続师を用い 2 段還元法で作つた. 第 1 段は $\mathrm{WO}_{3}$, または珪酸カリウムと磁酸アルミニウムをドープし た $\mathrm{WO}_{3}$ から $\mathrm{WO}_{2}$ に還元し, 第 2 段で $\mathrm{WO}_{2}$ から W 遅元した. $\mathrm{WO}_{3}$ は不揮発性残渣 $0.01 \%$ 以下の純パラタ ングステン酸アンモニウムを熱分解して作つた。第 2 段の 還元条件はとくに粉末の粒度に大きな影響をおよぼす・還 元温度 750 900 までの数段階を $1 \mathrm{hr}$ で経過し, と々に 乾燥した水素を用い，W $1 \mathrm{~g}$ 当り $1 \mathrm{~L} / \mathrm{sec}$ 流した。粉末を 電子顕微鏡で観察すると 1 ケ 1 ケが個々に分れた 1 次粒子

(5) 高柳：本誌, 24(1960),74. 
からなるものむあるが，大部分は 1 次粒子同士がドープ剂 を媒介とするくつつきや半融着などで結合しててできた 2 次 粒子, 怙よびこれらがさらに集つてできた大小様々の高次 粒子から成つている.

\section{III. 実 験 結 果および考察}

1. W粉末の比表面積におよほすトープと 製造後の処理の効果

Table 1 は水索還元後直ちに各種の酸またはアルカリ

Table 1 Surface area of $\mathrm{W}$ powders after treatment with dil. acid or alkaline solutions.

\begin{tabular}{l|r|r|r|c}
\hline & \multicolumn{4}{|c}{$S\left(\mathrm{~cm}^{2} / \mathrm{g}\right)$} \\
\hline \multirow{2}{*}{ Treatment } & \multicolumn{2}{|c}{ Doped } & \multicolumn{2}{c}{ Undoped } \\
\cline { 2 - 5 } & $\mathrm{D}-1$ & $\mathrm{D}-2$ & $\mathrm{P}-1$ & $\mathrm{P}-2$ \\
\hline No treatment & 1,060 & 1,120 & 7,420 & 2,950 \\
Pure water & 5,420 & 5,320 & 7,430 & 2,950 \\
$5 \% \mathrm{NH}_{2} \mathrm{OH}$ soln. & 5,380 & 4,780 & - & - \\
$5 \% \mathrm{KOH}$ soln. & 4,330 & 3,650 & - & 2,950 \\
$5 \% \mathrm{HF}$ soln. & 2,440 & 1,520 & 4,340 & 2,260 \\
$5 \% \mathrm{HCl}_{\text {soln }}$ & 9,100 & 7,820 & - & - \\
$5 \% \mathrm{H}_{2} \mathrm{SO}_{4}$ soln. & 10,500 & 10,090 & - & - \\
\hline
\end{tabular}

Both D-1 and D-2 were doped with $\mathrm{K}$-silicate and $\mathrm{Al}\left(\mathrm{NO}_{3}\right)_{3}$ respectively.

$\mathrm{D}-1,-2$ and $\mathrm{P}-1$ were reduced at 750 to $900^{\circ} \mathrm{P}-2$ was reduced at higher temperatures.

の稀溶液, あるいは純水のみで浸漬洗洒処理した $\mathrm{W}$ 粉末 の比表面積 $S$ と, 末処理の粉末の $S$ の比較を示す. 処理 の方法は粉末各 $25 \mathrm{~g}$ をそれぞれ各種の稀溶液に室温で $3 \mathrm{hr}$ 浸清した後浸漬液を捨て,メチルレッド指示薬で検査しつ
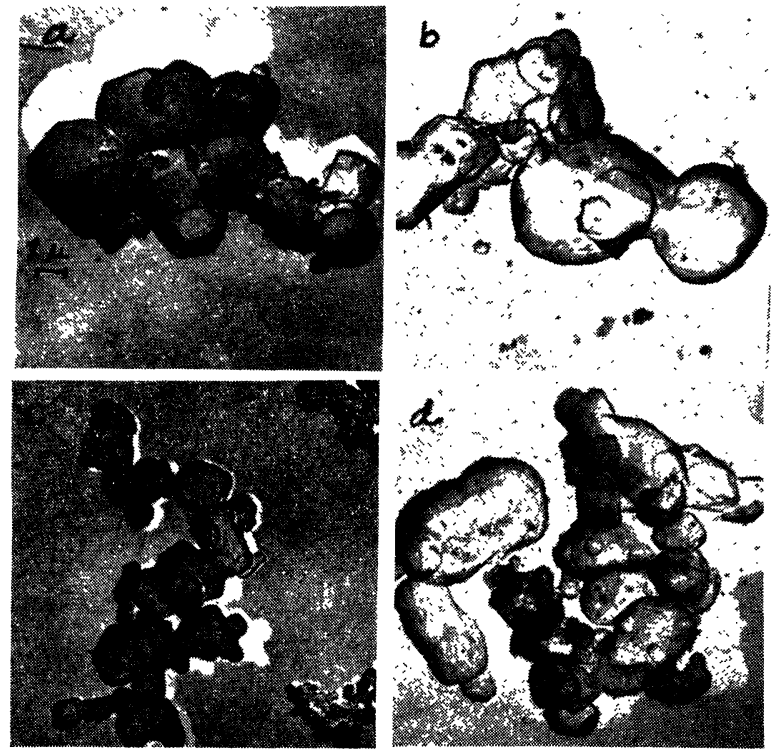

Photo. 1 Shapes and surfaces of $\mathrm{W}$ particles. $(\times 3000)$

(a): pure W powder (b): doped W-powder (c): doped powder (b), pure water treated

(d): same as above (c), $5 \% \mathrm{HCl}$ solutions treated.

つ純水で洗條を絽り返し, 酸またはアルカリ分を十分除 き, 直ちにガラスフィルターで滤過, 酸化を防ぐため $80^{\circ}$
で真空乾燥した・用いた溶液は特級試薬を純水で稀釈調整 した.

Photo.1 は表面状態を観察するのに適したカーボンレ プリカ法による粉末の電子顕微鏡写真である. 純 W 粉末 の $S$ は純水で洗つても汪とんど変らない，これに反して ドープした粉末の $S$ は同じ条件で還元した純 W 粉末の約 $1 / 7$ で非常に小さいが純水で洗うと約 5 倍にふえ, 純 W 粉末のそれに近ずく.この理由はドープした粉末は粒子相 互のくつつきとか, 表面がドープとくにアルカリで覆わ れて, 粒子間隌や表面の山凸が隠されているからであつ て、このようなドープを洗い去らなければ下地の W の $S$ とかなり異なつたものを示すことになる。しかるに Spier ら(3) が水菜還元で作られる W 粉末の粒度に扣よぼすドー プの効果を研究した結果, 拄酸カリウムをドープすると還 元過程に打いて粒子の生長が著しく, BET 法で決定した $S$ は純 $\mathrm{W}$ 粉末の 1/5〜1/6 になるといつているが，水洗 いの効果については述べていない. $\mathrm{NH}_{4} \mathrm{OH}$ などの稀アル カリ液に浸漬しても純 W 粉末の $S$ は変らないが, ドープ した粉末では水洗い後の $S$ よりもさい.しかしHFで妈 理した場合は両方ともSが著しく減る.とくにドープした 粉末の減少率は大きい.すなわち純 $\mathrm{W}$ 粉末が処理前の 約 0.6 になるのに比べ, ドープした粉末では水洗後の $S$ の $0.3 \sim 0.5$ に減る. 電子顕微鏡で観察すると Photo.1 (b) の如く, ドープした粉末は結晶粒子の輪郭が明らかで ないが，アルカリまたは $\mathrm{HF}$ 液で処理すると（c）の如く 明確になる.しかし純W 粉末の結晶粒子 (a)に比べると, 多面体の結晶形がくずれ丸味をおびている。また粒子表 面には小粒子のくつついていた跡か, ドープの洗い出され た跡と思われる凹部が比較的はつきりと認められる. $\mathrm{HCl}$, $\mathrm{H}_{2} \mathrm{SO}_{4}$ 溶液で処理したものの表面は非常に粗くS の大き いことと一致している.

かような $S$ の変化を考えてみると,W 粉末を酸素の溶 け込んでいるアルカリまたは HF の稀溶液に浸漬すると， Wが徐々に溶かされるので各粒子は多少小さくなることに なるが，微小粒子は消失し，ま充 W の溶解は恐らく多面体 の稜角部とか表面の凸部から進行するので, 粒子は滑らか で表面積の小さな丸味を扣びた多面体に近づき, 全体とし て $S$ が減ると考兄られる. 化学作用の強い $\mathrm{HF}$ がこの傾 向を最も顕著に示している. 一般にW 粉末は空気中では 室温でも酸化して粒子表面に酸化層ができたり，0.5 $\mu$ 以 下の微粒子の一部は酸化物になつているといわれている. ドープした W 粒子の裴面は前述のようにドープのアル カリで覆われていると考えられるので, この場合の酸化は 恐らくアルカリを通して抢こるのであろう. かような粉末 は酸化物のない粉末に比べて浸漬による $S$ の変化が大きい はずである.ドープした粉米（ただし水洗後）が純粉末よ り $\mathrm{HF}$ 処理による $S$ の減少率の大きいのは,酸化物や微粒 子が多いとか, 表面が複雑なことを示している. 電子顕微 鏡で 1 次粒子の大きさを比較すると, 純 W 粉末は大部分 
$1 \mu$ 前後の狭い分布をしているが，ドープした粉末はこの 部分が減り，著しく生長した大粒子括よび微粒子の割合が

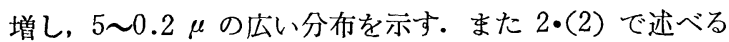
ようにドープした粒子のアルカリ被覆の下地面はドープの， 作用で凹凸の多い複雑な面となつていると思われる. $\mathrm{HCl}$, $\mathrm{H}_{2} \mathrm{SO}_{4}$ 溶液では粒子表面は侵蝕されて粗くなるとともに, 一度溶けた W や酸化物がコロイド状タングステン酸とな り析出して残るので $S$ が著しく增す.このことは, これ らの液で処理した粉末を $\mathrm{HF}$ またはアルカリで処理する と, もとの粉末を直接 $\mathrm{HF}$ などで処理したとさの $S$ に近 づくことからも推論できる.

\section{W 粉末 末 HF 処 理}

$\mathrm{W}$ 粒子は $\mathrm{HF}$ 処理で表面がきれいになり $S$ が減るこ とがわかつたので, この効果を一層明らかたするためドー プした粉末の $\mathrm{HF}$ 処理についてさらに調べた.

\section{（1）漫漬条件と此表面積}

ドープした粉末各 $30 \mathrm{~g}$ を用い溶液の濃度(3〜10\%), 浸 漬温度 $\left(0 \sim 30^{\circ}\right)$, および時間 $(0.5 〜 7 \mathrm{hr})$ を変えた場合 の $S$ の差異を調べた. $\mathrm{HF}$ 濃度, 浸漬温度を多少変えて も $S$ は殆んど変らなかつたが, Table 2 の如く $S$ は時

Table 2 Effect of pickling time on the surface area.

HF conc. : $5 \%$ Temp. : Room temp. $\left(18^{\circ}\right)$

\begin{tabular}{c|c|c}
\hline Pickling time (hr) & $S\left(\mathrm{~cm}^{2} / \mathrm{g}\right)$ & $\begin{array}{c}\text { Weight loss } \\
(\%)\end{array}$ \\
\hline Original powder after & 5,420 & - \\
washing with water & 1,670 & 2.7 \\
0.5 & 1,570 & 3.0 \\
1 & 1,370 & 3.2 \\
3 & 1,020 & 2.9 \\
7
\end{tabular}

間とともにほぼ值線的に減つた. しかし W の重量損失に はほとんど差異は認められなかつた。

\section{（2）ドープに及ほす HF 洗滌処理の影響}

Table 3 は前記純水または溶液処理後粉末に残 留する

Table 3 Contents of dopes remaining after treatment with dilute acid or alkaline solutions.

\begin{tabular}{l|c|r|r}
\hline \multirow{2}{*}{ Treatment } & \multicolumn{3}{|c}{ Residual dopes (\%) } \\
\cline { 2 - 4 } & $\mathrm{SiO}_{2}$ & $\mathrm{KCl}$ & $\mathrm{Al}_{2} \mathrm{O}_{3}$ \\
\hline Pure water & 46.0 & 23.0 & 68.5 \\
5\% KOH soln. & 52.0 & 21.5 & 70.0 \\
$5 \% \mathrm{HF}$ soln. & 11.8 & 3.0 & 16.5 \\
$5 \% \mathrm{HCl}$ soln. & 46.0 & 3.0 & 64.0 \\
\hline
\end{tabular}

各ドープ成分の量をもとの粉末に扑るとれらの含有量の 百分率で示す. 分析は塩素ガス捙散法で W を除いた残渣 について, 各元素の微量分析を行つた. KC1 はどの場合に も大部分洗い出される. $\mathrm{SiO}_{2}, \mathrm{Al}_{2} \mathrm{O}_{3}$ は $\mathrm{HF}$ 以外のもので 処理した場合は大半粉末に残るが, HF で処理すると大部 分が粉末から除かれる。これはドープ成分が殆んど粒子表 面にあつてこの処理で洗い流されるか, 或いは W の溶解 とともに表面の凹部にあるものが離脱してくるためであろ
ラ.アルカリは大部分可溶性の状態で粒子表面を覆つてい るが, 残留分はタングステンブロンズ(6)(7)の如き複雑な化 合物を作つていると思われる. $\mathrm{HF}$ に侵され易い $\mathrm{SiO}_{2}$ の 残留分は $\mathrm{Al}_{2} \mathrm{O}_{3}$ とともに表面の凹所に埋もれているか， W と不溶性化合物を作つているものであろう.他の実験に よるとかような HF 処理した粉末を用いて加工したW 棒, 線などの再結晶特性は，末処理の粉末を用いたものに比べ て平均して優つている，乙かしそれかといつて，HF 処理 後残つているドープと同程度の量の成分を還元前の酸化物 や金属粉末に最初から加兄ても，でき上つた棒または線の 特性はよくない。すなわち，W に及ぼすドープの効果は 粉末に残る部分にあるので洗い流される部分にはないとい ら重要な結論が出せる.

\section{（3） HF 処理した粉末の比表面積と粒度 について}

佐々木らの研究 ${ }^{(8)}$ によれば Wiegner の沈降法で W 粉 末の粒度分布を再現性よく求めるためには, 湘定に先立つ て粉末を $2 \mathrm{t} / \mathrm{cm}^{2}$ のプレスにかけて粒子同士のくつつき をこわし，1 次粒子に近い粒子にまで分離しなければなら ない。しかし HF で処理すると, 微粒子, 表面酸化物など は溶けて粒子は比較的滑らかな面をもつよ5になる。ま た，高次集合粒子を作つている粒子同土のくつつきが解 け，その結果粉末をプレスしたと同程度にまで粒子が分離 されることが電子顕微鏡観察でわからた・このことはまた Tapping 試験で求めた粉末の見掛比重が HF 処理前の約 2 倍にふえ(プレスしたときと同程度) ることからもわか る.したがつて粉末を $\mathrm{HF}$ 処理して後沈降法で测定した粒 度分布は再現性があり。電子顕微鏡で観測した粒度分布と も比較的よく合 5 . プレス, $\mathrm{HF}$ 処理などで十分 1 次粒子 にまで分離した $\mathrm{W}$ 粉末（水素還元で作つた）の粒度分布 を沈降法や電子顕微敛で測つた結果は対数型正規分布をと る(9). したがつて测定した分布から統計的手法を用い，平 均粒径 Dst が求められる*。またガス吸着法で求めた $S$ か 与次式

$$
d v_{s}=6 / \rho S \rho: \text { 固体の比重 }
$$

により等価粒径 $d v s$ が求められる． $S$ は粒子を構成する 1 次粒子の大きさだけでなく，その表面状態に著しく左右 されるので, この $d v s$ は一般に他の色々な方法で求めた 粒径より小さいばかりでなく, 相関が求め難いと従来いわ れて来た。しがし $\mathrm{HF}$ 処理すると沈降法の测定結果から求 めた Dst と, $S$ からの $d v s$ との間には直線関係のある

(6) Gmelin: Handbuch der Anorg. Chemie, Wolfram, (1933), 235

（7）潮田，中沢，照井：本誌, 16(1952), 63.

（8）佐々木, 上田, 小笹: 京大化研報告, 25(1951), 66 。

(9) F.Kottler : J.Phys. Chem., 56(1954),442；上田, 小笹：タングステン粉末の粒度分布 (末発表).

* 粒子を球と仮定し，その分布径が対数正規分布になる とすると, 重量分布の最大分布径 $D w$ と平均重量をも つ粒子の平均粒径 Dst の間には次の関係が成立する. $D s t=D w \exp (-1 / 4 a)$

ただし $a$ は分布の標準偏差を $\sigma$ とすると $a=1 / 2 \sigma^{2}$ 
ことがわかつた. すなわち Fig.1 にドープした粉末を $5 \% \mathrm{HF}$ 溶液で $3 \mathrm{hr}$ (室温) 浸漬処理して, それぞそWie-

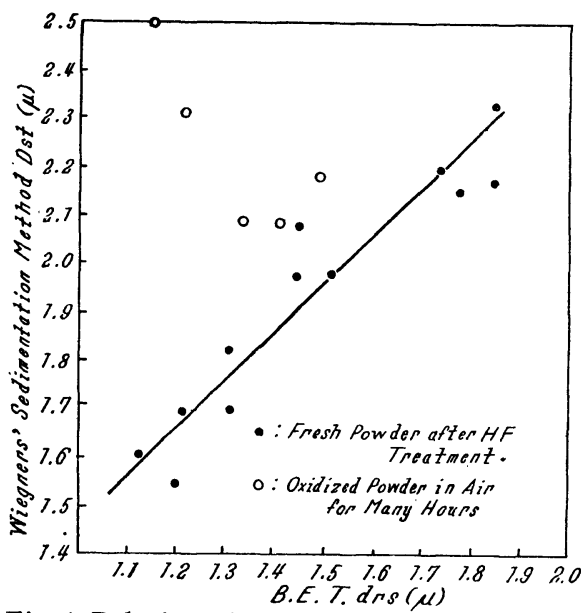

Fig.1 Relations beetwen equivalent particle size evaluated from B.E.T. surface area and statistical average particle size evaluated from the size distribution by sedimentation method.

gner 法 と $\mathrm{BET}$ 法で測定 した粒径 の関係を 示す.

Fig.1の 対応は等 価粒径 1 $\mu$ 以下 (BET 法で)に なると沈 降法の測 定誤差が 大きくな り成立し 難くなるまた 3 で述べる如く $\mathrm{HF}$ 処理しても, 暫く空気 中に放置したため酸化して表面状態の変つた粉末などにつ いてはこの対応は成立しなくなる。

上記の実験から W 粉末を $\mathrm{HF}$ 処理すると粒子は比較的 滑らかな 1 次粒子にまで分れるので，いろいろな測定法で 測つた結果がよく一致する。そしてこのような場合には BET 法で測定した $S$ が粒度を表わす尺度として使えるで あろ5

\section{W粉末の酸化, 還元と比表面積}

前節でふれた室温大気中における $\mathrm{W}$ 粉末の酸化と, そ れに伴う表面状態の変化を調べるため次の如く酸化速度及 び $S$ の变化率を求めた. 実験試料は $\mathrm{A}$ : 純 $\mathrm{W}$ 粉末, $\mathrm{B}$ : ドープした粉末， C : B を HF 処理した粉末の 3 種類であ る. A は還元炉から水素気流中で採取した直後のもの, C は真空乾燥值後のもので, 試料各 $10 \mathrm{~g}$ を径 2 in の時計血

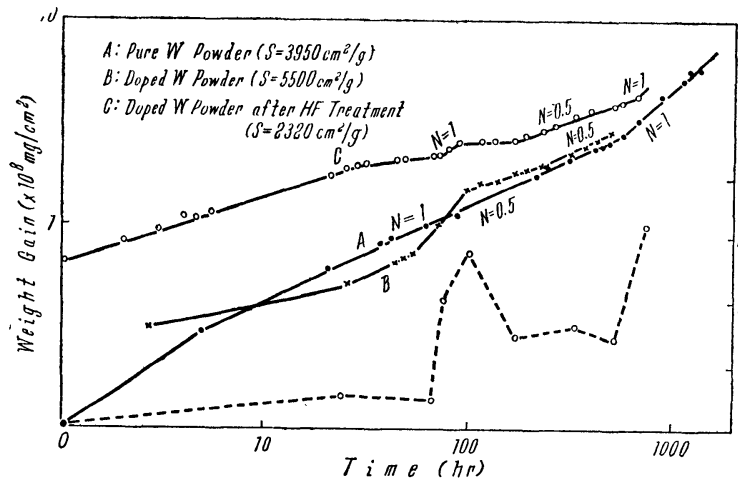

Fig.2 Oxidation and surface area increase of $\mathrm{W}$ powder in atmospheric air at room temperature. $N$ : Slope of $\log -10 \mathrm{log}$ plots.

に拡げた後の重量増加を化学天科で測つたが，Bはアルカ リによる吸湿分を考虑して, 水蒸気圧約 $13 \mathrm{mmHg}$ （測定

時の大気湿度に相当する）の湿つた水素需囲気中で吸湿を 飽和させて後, 同様にして重量増加を測定した. $S$ の変化 率は $S$ についてのみ求めた. Fig.2 はこれらの粉末の酸 化による重量增加之時間の関係を表わす代表的な両対数グ ラフである．また比較を容易にするため，同じ時間軸に対 し S の変化率をもとつた. 純 $\mathrm{W}$ 粉末 $\mathrm{A}$ は勾配 0.5 の直 線となり酸化が抛物線則に従つていることが判る.しかし $600 \mathrm{hr}$ の辺で折線が生じ勾配 1 の直線に移つている.ドー プした粉末 $\mathrm{B}$ とそれを $\mathrm{HF}$ 処理した $\mathrm{C}$ はこれに比べる と複雑で, 勾配 0.5 以下, 0.5 扣よび 1 の直線部分が繰返 している.しかしいずれの場合も初め保護性の酸化皮膜を 作つて進む（勾配ミ0.5）がある，時間たつと非保護性の酸 化を示す直線則に従うようになる。この勾配の転移に伴な いFig.2 の点線で示すように $S$ の増加率の様子が著しく 変る・すなわち保護性の皮膜形成段階では $S$ はほとんど変 らず, 非保護性の酸化に移ると急に増すことは意義深いこ

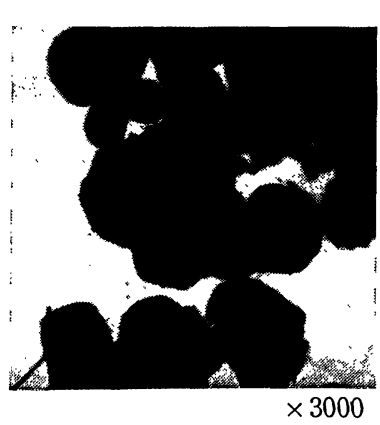

Photo.2 Roughed surface of naturally oxidized powder (doped) in air for $100 \sim 200 \mathrm{hr}$.
とである.これに関連し て電子顕微鏡的観察の結 果は,かように $S$ の增え た粉末には Photo.2 の 如く多数の微細針状結晶 の発生が認められる.こ の突起は粉末を水洗いし ただけでは消えないが， $\mathrm{HF}$ やアルカリの稀溶液 で処理すると消えて平滑 な面となる・これに伴つ て $S$ も減る・またかよう な粉末を乾燥した水素で還元しても同様に平滑な面とな る. Table 4 は HF 処理直後の粉末と処理後大気中で酸 化し，S の增えた粉末をそれぞれ石英バルブで測定した還 元前後の $S$ を示す.

かように酸化の過程で発生する針状結晶は W 酸化物と 考学られ保護性の酸化から直線則に移る段階で酸化皮膜に

Table 4 Surface areas of $\mathrm{W}$ powder before and after $\mathrm{H}_{2}$ re-reduction. Temperature : $800^{\circ}$, Time $: 1 \mathrm{hr}$

\begin{tabular}{c|c|c|c|c}
\hline & \multicolumn{4}{|c}{$S\left(\mathrm{~cm}^{2} / \mathrm{g}\right)$} \\
\hline Specimen & Fresh powder & Oxidized powder \\
\cline { 2 - 5 } & D-3 & D-4 & D-3 & D-4 \\
\hline Before & 2,200 & 1,200 & 6,200 & 3,840 \\
Aftere & 2,100 & 1,250 & 1,570 & 1,880 \\
\hline Change in S $(\%)$ & -4.5 & +4.2 & -74.8 & -51.0 \\
\hline
\end{tabular}

Fresh powder: doped powder, treated with $\mathrm{HF}$ after normal reduction respectively.

Oxidized powder: D-3: for 30days, D-4: for 15 days oxidized in atmospheric air.

亀裂が発生し, その後生成した酸化物は（転移前に生成し ていた酸化物も恐らく) 移動して, 針状に生長してゆくの 
であろ5・しかし前述の通り 0.5〜1.0 のサイクルが繰返 される故に, ある程度結晶生長が進むと再び保護性酸化に

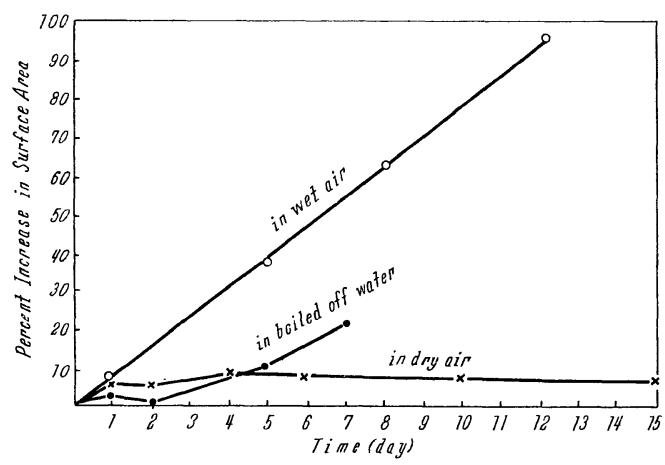

Fig.3 Percent increase in surface areas of the same W powder (after HF treatment) stored under different conditions.

移ることもあると考えられる。次に最初の転移の起る時間 について考えてみる. Fig.3 はドープした粉末を HF 処理
後純水, 高湿度空気拉よび乾燥空気中に保存した場合の $S$ の増加率を示す.これらの結果をみると湿気のある空気中 では $S$ は増すが，湿気がなければ殆んど変らない。また空 気を絶つた水中で増加も少ない（S の増加は測定試料をと り出す時空気が水に溶け込んだためで, 完全に空気を絶て ば恐らく $S$ は変らないであろう).かように空気中での $S$ の増加, すなわち直線則に移る時間はドープしてあれば短 かくなり，また湿つた空気中では最初から直線則に従うこ ともあると考えられる. また粒度, ドープの種類によつて もこの時間が変ることが他の実験で認められている.

\section{IV. 結}

以上簡易 BET 法を用いてW 粉末粒子の表面状態执よ びそれに影響を与える二三の要因について論じた。

終りに本研究を遂行するに当つて, 絶えず留切なる御指 導を賜つた京都大学佐々木申二教授に深く感謝の意を表し ます。また発表を許可された松下電子工業株式会社および 実験に協力された沢田良治氏に厚く和礼申し上げます. 